\title{
Laryngeal height and voice characteristics in children with autism spectrum disorders*
}

\author{
Jung-Hun Lee ${ }^{1,2} \cdot$ Go-Woon $\mathrm{Kim}^{2} \cdot$ Seong-Tae Kim ${ }^{1, * *}$ \\ ${ }^{I}$ Department of Speech-Langugae Pathology, Dongshin University, Naju, Korea \\ ${ }^{2}$ DIRFloortime Korea, Seoul, Korea
}

\begin{abstract}
The purpose of this study was to investigate laryngeal characteristics in children with autism spectrum disorders (ASD). A total of 50 children participated, including eight children aged 2 to 4 years old diagnosed with ASD and 42 normal controls at the same age. All children recorded X-ray images of the midsagittal plane of the cervical spine and larynx, and compared the laryngeal positions of ASD and control. In addition, samples of children with vowel prolongation were collected and analyzed for acoustic parameters. X-rays showed that the height of the hyoid bone in the normal group was the lowest at 3 years of age, and ascended at 4 years of age. Nevertheless, the distance from the external acoustic meatus to the hyoid bone was longest at age 4. 4-year-olds with explosive language development showed laryngeal height elevation and anteriorization. In contrast, the hyoid height of the ASD group of all ages was lower than that of the control group, and there was no difference in the hyoid position between the ages. As a result of acoustic evaluation, PFR, vFo, and vAm were significantly higher ASD than control. Low laryngeal height of ASD children may be associated with delayed language development. PFR, vFo, and vAm seem to be voice markers showing the difference between normal and ASD children.
\end{abstract}

Keywords: autisum spectrum disorders, laryngeal height, PFR, vFo, vAm

\section{1. 서론}

인간의 음성(human voice)은 물리적인 움직임의 결과물이다. 인간은 신체를 움직이는 것처럼 음성 산출에 필요한 근육들을 순차적으로 움직여서 진동을 만든다(Jeong, 2003). 숨을 내숼 때 폐의 폐포에서 가스교환이 일어난 날숨이 기관지를 거쳐 기도 를 타고 올라와 후두(larynx)를 지나게 된다(Jeong, 2003; Seikel et al., 2013). 이때 후두를 지나는 공기가 성대(vocal folds)에 부딪 혀 성대의 진동을 만들게 되고, 이 진동은 말소리를 생성한다(Jeong, 2003). 이는 소리의 높이를 결정하는 기본주파수(fundamental frequency, 이하 Fo)와 크기를 결정하는 진폭(amplitude, 이하 Am) 으로 구성된다(Ferrand, 2011; Sataloff, 2005).

말소리는 호흡, 발성, 공명, 조음 기관들의 상호 협응 작용에 의해 산출되며, 중추신경계와 말초신경계에 의해 통제되고 조

\footnotetext{
* This study was prepared by correcting and securing the master's thesis of Jung-Hun Lee (2018).

**voicekim88@hanmail.net, Corresponding author

Received 3 June 2021; Revised 12 June 2021; Accepted 12 June 2021

(c) Copyright 2021 Korean Society of Speech Sciences. This is an Open-Access article distributed under the terms of the Creative Commons Attribution NonCommercial License (http://creativecommons.org/licenses/by-nc/4.0) which permits unrestricted non-commercial use, distribution, and reproduction in any medium, provided the original work is properly cited.
} 
절된다(Ferrand, 2011). 성문(glottis)에서 만들어진 지속적인 성 대 진동은 성도(vocal tract)를 지나면서 다양한 종류의 말소리로 변화되어 구강과 비강을 통해 대기로 나오게 된다(Seikel et al., 2013). 공기입자들의 충돌을 통해 전달된 말소리 진동은 고막을 다양하게 두드리고, 이소골 연쇄와 내이를 지나면서 신경 임펄 스로 변환되어 청신경을 통해 뇌로 전달된다. 뇌로 전달된 신경 임펄스는 청각언어센터로 전달되어 인식되고 해석된다. 성문에 서 만들어진 성대 진동은 이와 같은 경로를 거쳐 언어의 재료가 된다(Benninger et al., 2016; LaPointe et al., 2010; Sataloff, 2005).

후두는 출생 후 성장하면서 급격한 위치의 변화를 가져온다. 선행 연구에 따르면, 신생아와 영아들의 후두는 포유류와 유사 하게 높게 위치 해 있는데, 이로 인하여 호흡을 하는 동시에 삼킴 이 가능하다고 보고하였다(Laitman et al., 1977). 또한 Magriples \& Laitman(1987)은 신생아와 영아들의 높은 후두 위치가 생후 1 세 6 개월에서 2 세 전까지는 1 번 경추(cervical vertebrae, 이하 $\mathrm{C1}$ ) 의 기저부와 4 번 경추(C4)의 상부 사이에 위치 하지만, 2 세 이후 천천히 하강하여 $\mathrm{C} 2$ 와 $\mathrm{C} 5$ 사이 높이로 위치한다고 보고하였다.

언어학적인 관점에서 신생아의 높은 후두 위치는 소리를 다 양하게 변화시키지 못하는 결과를 초래한다. 비록 높은 후두의 위치 때문에 호흡 통로와 삼킴 통로가 동시에 존재 하는 것이 가능하지만, 이로 인해 신생아와 영아들은 다양한 소리를 발생 시키기 어렵다(Laitman et al., 1977; Lieberman, 1984; Sasaki et al., 1977). Lieberman(1984)은 그의 저서에서 높게 위치한 후두 가 상인두 공간을 좁게 만들면, 성대가 다양한 소리를 산출하는 것이 크게 제한된다고 보고하였다. 따라서 신생아나 원숭이처 럼 후두의 높이가 높으면, 그렇지 않을 때와 비교하여 발성의 범위가 현저하게 제한하는 것으로 보고하였다.

Laitman \& Crelin(1976)과 Lieberman et al.(1992)은 신생아와 원숭이에게 산출되어지는 비연속적으로 발성된 모음을 확인한 결과, 특정 모음 $/ \mathrm{i} /, / \mathrm{u} /, / \mathrm{a} /$ 가 인간의 신생아와 다른 포유류들이 만들어낼 수 없는 소리였다고 보고하였다(Laitman \& Reidenberg, 1993). 후두는 2세 이후 계속 하강하여 7세에는 C3와 C5의 기저 부 사이에 위치하게 된다. 성인이 되면 $\mathrm{C} 4$ 와 $\mathrm{C} 7$ 의 상단부까지 하강하게 되며, 이런 장기간에 걸쳐 지속적으로 이루어진 후두 의 하강은 매우 다양한 종류의 소리 산출을 가능하게 하고, 이 와 같은 후두의 하강은 다른 동물들과 구별되는 인간의 뚜렷한 특징이라고 보고하였다(Laitman \& Crelin, 1976).

Türkmen et al.(2012)은 x-Ray 방사선 촬영을 통해 300명의 측 면 경부 촬영(lateral cervical imaging)을 분석하여 후두에 위치한 연골들의 변화 정도를 보고하였는데, 갑상연골과 윤상연골은 생후 10 년이 지나면서 골화가 진행되는 게 방사선 사진에서 점 차 관찰된다고 보고하였다. 모든 후두 내의 연골들은 매우 느리 게 경화가 지속되는 반면에, 설골은 10 세 전에 경화가 이루어져 서 몸통(body) 부분과 대각(greatest horn) 부분의 구별이 가능해 지고, 30 세가 지나면서 단일의 뼈로 완성된다고 보고하였다.

한편, 신경발달장애(neurodevelopmental disorders)로 분류되 는 자폐스펙트럼장애(autism spectrum disorders, 이하 ASD)는 사 회적 의사소통 및 상호작용의 지속적인 제한을 보이며, 반복적인 운
동이 나타나고 동일성에 대한 고집을 보이는 장애이다(diagnostic and statistical manual of mental disorders 5th, DSM-5; American Psychiatric Association., 2013).

몇몇 선행 연구들에서 $\mathrm{ASD}$ 아동들의 비정상적인 음성 특성 을 확인해 볼 수 있다. Wing(1992)은 정상 유아들과는 다르게 ASD 유아들이 주고받는 전략(turn-taking strategy)이나 적절한 비언어 의사소통(body language)뿐만 아니라, 발화 시에도 음성 의 높이와 억양을 사용하는 것에 제한이 있다고 보고하였다. Bregman(2005)은 ASD 아동들이 사회적인 얼굴표정(socially facial expressions)을 상황에 맞게 사용하지 못할 뿐만 아니라, 정 서를 제스처로 표현하거나 억양과 같은 언어의 초분절적인 요소 를 사용하여 발화하는데 심각한 손상이 있다고 보고하였다.

최근에, Nakai et al.(2014)은 ASD 아동 26명과 동일 연령대의 정상 아동 37명의 말소리의 높낮이(speech intonation)를 분석한 결과, $\mathrm{ASD}$ 아동들의 발화 시 최고 음도(great pitch)가 정상 대조 군 아동들의 음도보다 더 낮은 것으로 나타났으며, 결과적으로 $\mathrm{ASD}$ 아동들이 정상 대조군 아동들에 비하여 단조로운 말소리 억양(monotonous speech)을 사용한다고 보고하였다.

또한, Smerbeck(2015)은 ASD 아동들과 동일 연령대의 정상 아동들의 발화 시 비음도를 청지각적으로 평가한 결과, $\mathrm{ASD}$ 아 동들의 음성이 정상 대조군 아동들에 비해 더많은 비음이 산출 된다고 보고하였고, Baltaxe(1981)는 정상 아동들이 발화 시 구 문의 형태를 음도 변화로 표현하는데 반해, ASD 아동들은 강도 변화로 구문의 형태를 표현하는 운율특성을 보이며, 정상아동 들에 비해 매우 넓은 강도 범위를 사용한다고 보고하였다.

앞선 선행연구들을 종합해 보면, 정상 아동들의 후두 발달이 나 연골들의 구조적 변화에 대한 연구는 찾아볼 수 있지만, 언 어발달이 지연되는 아동들의 후두 특징 및 후두 발달에 대한 연 구는 아직까지 보고된 바 없었다. 특히 지속적인 언어발달 지연 을 보이는 $\mathrm{ASD}$ 아동의 후두 특징은 아직까지 보고된 바 없다.

또한, ASD 아동들의 발화 시 운율, 기본주파수, 비음 등과 같 은 초분절적 요소들에 대한 연구는 지속적으로 보고되고 있으 나, 발성장애의 유무를 평가할 수 있는 모음발성 시 음향학적 변수들의 이상 유무를 보고한 연구는 아직까지 없는 실정이다. 발성기능 평가에서 모음연장 발성은 음질을 판단하는데 유용 하며, 정상적인 모음 발성 시 음질은 안정되고 균일하며 부드럽 고 명확하다. 또한 모음 연장 발성은 거친 음질이나 쥐어짜는 음질 그리고 낮은 음도 등과 같은 발성기능 결함을 찾아내는데 매우 유용하다고 보고된 바 있다(Freed, 2012).

이에 본 연구는 $\mathrm{ASD}$ 아동들의 후두 위치 특성과 모음 발성 시 나타나는 음향학적 변수들의 특징을 동일 연령대 정상 아동 들과 비교해 보고 어떠한 차이가 있는지 확인해 보고자 하였다.

\section{2. 대상 및 방법}

\section{1. 대상}

$\mathrm{ASD}$ 로 진단되어 언어치료실에 내원한 2세에서 4세까지 $\mathrm{ASD}$ 아동 15 명과 동일 연령대의 정상 아동 94 명, 총 109 명을 대상 
으로 하였다. 본 연구는 동신대학교 생명윤리위원회(Institutional Review Board, IRB)의 승인을 얻어 진행하였다. 대상자들은 한 국형 아동기 자폐증 평정 척도(The Korean Version of Childhood Autism Rating Scale, CARS), 영·유아 언어발달검사(sequenced language scale for infants, SELSI; Kim, 2014)를 사용하여 자폐성 척도를 측정하고 언어발달을 평가하여 연구의 목적에 부합하 는 아동을 선정하였다.

대상자는 모두 남아로 제한하였으며, 연령분포는 2 세에서 4 세로 하였다. 대상자의 연령과 성별을 제한 한 이유는 후두의 하강이 2 세 전후로 나타나기 시작하며 남아가 $\mathrm{ASD}$ 출현율이 높기 때문에 실험군과 대조군을 모두 남아로 선정하였다.

연구에 앞서 모든 대상들 중 다음과 같은 사항을 가진 대상자 들은 연구에서 제외하였다.

첫째, 만성 호흡기 질환 또는 상기도 감염 소견이 있는 자.

둘째, 기타 질병으로 약물을 장기 복용해 왔거나 복용하는 자. 셋째, 경도 이상의 청력손실을 가진 자.

넷째, 장기간 삽관을 시행한 수술이나 기관절개술을 받은 자. 다섯째, 다운증후군 등과 같은 기타 유전적 장애가 있는 자. 여섯째, 시각장애나 뇌병변과 같은 신체적 장애가 있는 자. 일곱째, 구개파열, 설소대 단축증 등 기질적 문제가 있는 자. 여덟째, 정상 대조군 중 언어발달 지연 또는 발달 지연이 의 심되는 자.

15 명의 $\mathrm{ASD}$ 아동 중 7 명은 X-Ray 사진 촬영 시 측면검사 결 과 촬영 실패로 간주하여 대상에서 제외되어, 나머지 8명의 $\mathrm{ASD}$ 아동만이 실험에 참가할 수 있었다(표 1). 8명의 ASD 아동 음성샘플 중에서도 발성 지속시간이 짧거나 강도가 적절하지 않은 2 개의 음성샘플은 본 연구에서 제외되어 6 개의 음성샘플 만 실험에 사용할 수 있었다.

정상 대조군 아동 94 명 중 측면 검사 상 촬영에 실패하거나 개인적인 이유로 실험에 참여하지 못한 48 명 아동이 제외되었 고, 언어발달 지연이 의심되는 정상 아동 3 명, 설소대 단축증을 갖은 정상 아동 1 명 또한 연구에서 제외되어 42명(2세, 11명; 3 세, 17명; 4세, 14명) 아동만이 최종적으로 본 연구에 참여할 수 있었다.

또한 정상 아동들 중 언어치료실에 내원하여 음성샘플 수집 에 참여한 아동은 모두 15 명 이었는데, 그 중 2 명의 아동은 음 성장애가 의심되거나 불안정한 음성때문에 실험에서 제외되었 고, 또 다른 2 명의 아동도 음성 녹음 시 지나치게 긴장하여 음 성분석이 가능한 음성이 수집되지 않았기 때문에, 11 명의 음성 샘플로 실험을 진행할 수밖에 없었다. 이리하여 ASD 아동 8 명 과 정상 대조군 아동 42 명을 포함한 총 50 명의 대상자들로 실 험을 진행하였다.
표 1. $\mathrm{ASD}$ 아동 특성

Table 1. Characteristics of ASD group

\begin{tabular}{c|c|c|c|c}
\hline $\begin{array}{c}\text { Subject } \\
\text { No. }\end{array}$ & Sex & Age & $\begin{array}{c}\text { 통합언어연령 } \\
\text { (SELSI) }\end{array}$ & CARS \\
\hline S1 & M & $2: 7$ & $0: 7$ & Severe \\
\hline S2 & M & $2: 11$ & $2: 4$ & Mild-moderate \\
\hline S3 & M & $3: 0$ & $1: 3$ & Mild-moderate \\
\hline S4 & M & $3: 1$ & $1: 3$ & Mild-moderate \\
\hline S5 & M & $3: 6$ & $1: 2$ & Mild-moderate \\
\hline S6 & M & $3: 8$ & $0: 11$ & Mild-moderate \\
\hline S7 & M & $4: 6$ & $1: 10$ & Mild-moderate \\
\hline S8 & M & $4: 9$ & $1: 2$ & Mild-moderate \\
\hline
\end{tabular}

ASD, autism spectrum disorders; SELSI, sequenced language scale for infants; CARS, childhood autism rating scale(아동기 자폐증 평정 척도).

2.2. 평가도구

\subsubsection{X-ray 촬영}

HITACHI사의 Disital Rediography system을 사용하여 방사선 촬영을 하였고, 정중시상면(midsagittal plane)을 촬영하여 기록 하였다. 경추를 기준으로 한 설골바디(body of hyoid bone, $\mathrm{BH}$ ) 의 상단 높이, 외이도(external acoustic meatus, EAM)에서 $\mathrm{BH}$ 상 단까지의 거리, 하악모서리점(gonion of mandible, $\mathrm{GM}$ )에서 $\mathrm{BH}$ 상단의 거리를 각각 측정하였다. $\mathrm{EAM}$ 과 $\mathrm{GM}$ 은 X-ray 시상면 판 독 시 기준점이 되는 좌표로 각각의 기준 지점과 설골까지의 거 리를 측정하여 그차이를 함께 비교하였다.

X-ray 촬영 시 아동은 수직격자장치 앞에 측면자세(lateral position)로 서고 검사면 쪽 어깨를 상수용판(image receptor)에 밀착시킨 후, 수직 격자 장치나 촬영대의 중앙선에 관상면 (coronal plane)의 중심을 일치시켰다. 외이도(EAM)의 위쪽 약 5 $\mathrm{cm}$ 의 위치에 상수용판(IR) 끝을 맞추었고, 양 어깨는 같은 수평 면에 놓이게 조정하였다. 또한 하악골(mandible)과 경추 윗부분 이 겹쳐지는 것을 방지하기 위하여 턱을 약간 앞쪽으로 내밀게 하여 촬영하였다(Bontrager et al., 2005).

\subsection{2. 음향학적 검사}

$\mathrm{ASD}$ 아동과 정상 대조군 아동의 음성을 분석하여 비교하기 위해 CSL(Model 4300B, Kay Elemetrics Corporation, Lincoln Park, NJ., U.S.A.)의 MDVP를 시행하여 대상자들의 음성을 평가 하였다. MDVP를 사용하여 기본주파수(Fo), 최대기본주파수(Fhi), 최저기본주파수(Flo), 기본주파수범위 세미톤(PFR), 주파수변 동률(jitter), 진폭변동률(shimmer), 소음대배음비(NHR), 음성난 기류지수(VTI), 약한음성지수(SPI), 주파수변화량(vFo), 진폭변 화량(vAm) 같은 음성 파라미터들을 분석하여 비교하였다.

2.3. 측정

\subsubsection{X-ray 촬영 및 판독}

X-ray 촬영 시 촬영자는 아동의 보호자에게 촬영에 대한 기본 정보를 제공하였고, 방사선을 이용한 촬영에 대한 과도한 불안 
감을 감소시키기 위하여 X-ray 방사선 촬영의 안전함에 대해 충 분하게 숙지하도록 설명 하였다. 촬영 시 아동이 불안을 느끼거 나 긴장을 했을 때 부모의 협조를 구하여 아동의 불안과 긴장을 낮추어 성공적인 촬영을 유도하였다.

특히, $\mathrm{ASD}$ 아동들은 낮선 공간에 대한 거부감과 의료장비에 대한 두려움을 느낄 수 있기 때문에 아동의 불안감과 긴장을 최 소화하기 위해 부모 혹은 담당 언어재활사가 동행하여 편안하 게 촬영을 할 수 있도록 협조하였다. 또한, 방사선 선량을 최소 로 낮추고 촬영하였고 촬영 도중 아동이 발화를 시도하거나 턱 을 당기는 등의 부적절한 자세를 취할 경우 자세 보정 후 재촬 영하였다.

판독에 사용된 촬영사진은 $\mathrm{GM}$ 이 경추 윗부분 $(\mathrm{C} 1 \sim \mathrm{C} 2)$ 과 겹 쳐지지 않고 양쪽 하악 가지는 똑같이 겹쳐져 있으며, 뼈와 연 조직을 잘 볼 수 있을 정도로 적정한 사진들만 연구에 사용하도 록 분류하였다. 이렇게 촬영된 X-ray 사진을 분석하여 정상발달 아동들의 $\mathrm{BH}$ 상단의 높이, EAM에서 $\mathrm{BH}$ 상단까지의 거리, $\mathrm{GM}$ 에서 $\mathrm{BH}$ 상단까지의 거리를 측정하여 연령별 특징을 분석하였 고 이를 ASD 아동과 비교하였다.

또한 정확한 후두 방사선 촬영 소견을 확인하기 위하여 방사 선과 전문의 1 인과 이비인후과 전문의 1 인의 판독을 통하여 공 통된 판독 결과를 채택하였고, 정상 아동들과 후두 방사선 촬영 소견을 비교하여 그 차이를 객관적으로 수치화하고 기록하였 으며 대상자들의 방사선 촬영 기록을 비교 분석하였다.

\subsection{2. 음향학적 평가 및 분석}

$\mathrm{ASD}$ 아동과 정상 대조군 아동의 음성샘플은 SONY PCMD100 voice recorder를 사용하여 수집하였다. 특히, 의미있는 음 성분석이 가능한 음성녹음기준인 $44,100 \mathrm{~Hz}$ 표본추출률과 16 bit로의 양자화로 음성 샘플을 표집하였다.

$\mathrm{MDVP}$ 검사 시 환경음과 같은 소음이 차단된 방에서 녹음을 실시하였고, 아동의 입에서부터 녹음기 마이크까지의 거리는 약 $5 \mathrm{~cm}$ 로 하였으며, 지속적인 모음 $/ \mathrm{a} /$ 를 3 회 정도 발성하여 2 초 이상 지속모음을 채택하였고 이 중 안정구간을 구하여 분석 했다. 이 때, 편안한 상태의 발성을 유도하기 위해 음성 수집 전 에 충분한 연습을 시행하였다.

\section{4. 통계분석}

$\mathrm{ASD}$ 아동 후두발달의 연령별 특성을 살펴보기 위해 기술통 계를 실시하였다. 그리고 정상 대조군 아동 2 세에서 4세까지 각 각 연령별 후두 위치를 비교하기 위해 SPSS for windows 23.0를 이용하여 일원분산분석(one-way ANOVA)을 실시하였으며, 음 성검사 후 그룹 간 평가된 자료의 음성매개변수를 비교하기 위 하여 Mann-Whitney U test를 시행하였고, 유의 수준은 .05 이하 로 하였다.

\section{3. 결과}

3.1. 정상 아동의 연령별 후두 위치 비교

\subsection{1. 연령별 설골의 높이 비교}

연령별 설골 높이를 비교하기 위해 X-ray 촬영 후 정상 아동 들의 $\mathrm{BH}$ 상단 높이를 경추 높이와 비교해 본 결과, 2 세 아동의 설골 높이 $(2.36 \pm 1.43)$ 가 가장 높았고, 그 다음으로 4세 아동의 설골 높이(3.64 \pm 1.94$)$ 가 두 번째로 높았으며, 3 세 아동의 설골 높이(4.41 \pm 0.84 )가 가장 낮은 것으로 확인되었다(표 2, 그림 1). 연령별 설골의 높이를 비교해 본 결과, 연령 간에 설골 높이는 통계학적으로 유의미하게 차이가 있는 것으로 나타났다 $(p<.05$, 표 3). 연령대별로 설골의 높이가 어떤 차이가 있는지 확인하기 위해 Dunnett 사후검정을 실시한 결과, 2 세와 3 세의 설골의 높 이가 통계학적으로 유의미하게 차이가 있는 것으로 나타났다 $(p<.05$, 표 4$)$. 반면, 2 세와 4 세의 설골 높이는 유의미한 차이가 없는 것으로 나타났으며, 3 세와 4세간의 설골 높이도 통계학적 인 차이는 없는 것으로 나타났다.

표 2. 정상 아동의 연령별 후두 위치 측정 결과

Table 2. Measurement results of laryngeal height in normal

\begin{tabular}{c|c|c|c|c|c|c|c}
\hline & Age & No. & Mean & $S D$ & $\begin{array}{c}\text { Std. } \\
\text { error }\end{array}$ & $\begin{array}{c}\text { Lower } \\
\text { bound }\end{array}$ & $\begin{array}{c}\text { Upper } \\
\text { bound }\end{array}$ \\
\hline \multirow{3}{*}{ BH } & 2 & 11 & 2.36 & 1.43 & 0.43 & 1.40 & 3.33 \\
\cline { 2 - 8 } & 3 & 17 & 4.41 & 1.94 & 0.47 & 3.42 & 5.41 \\
\cline { 2 - 8 } & 4 & 14 & 3.64 & 0.84 & 0.23 & 3.16 & 4.13 \\
\hline \multirow{2}{*}{ EAM- } & 2 & 11 & 6.09 & 0.30 & 0.09 & 5.89 & 6.29 \\
\cline { 2 - 8 } BH & 3 & 17 & 6.47 & 0.51 & 0.13 & 6.21 & 6.74 \\
\cline { 2 - 8 } & 4 & 14 & 6.71 & 0.73 & 0.19 & 6.29 & 7.13 \\
\hline \multirow{2}{*}{ GM- } & 2 & 11 & 1.91 & 0.30 & 0.09 & 1.71 & 2.11 \\
\cline { 2 - 8 } BH & 3 & 17 & 1.59 & 0.51 & 0.12 & 1.33 & 1.85 \\
\cline { 2 - 8 } & 4 & 14 & 1.93 & 0.62 & 0.17 & 1.57 & 2.28 \\
\hline
\end{tabular}

$\mathrm{BH}$, body of hyoid bone; EAM, external acoustic meatus; GM, gonion of mandible.

표 3. 정상 아동의 연령별 후두 위치 비교 Table 3. Comparisons of laryngeal height in normal

\begin{tabular}{c|c|r|r|r|r|c}
\hline Domain & & \multicolumn{1}{c|}{ SS } & $d f$ & \multicolumn{1}{c|}{ MS } & $F$-value & \multicolumn{1}{c}{ Sig. } \\
\hline \multirow{3}{*}{ BH } & BG & 28.027 & 2 & 14.014 & 6.081 & $.005^{*}$ \\
\cline { 2 - 7 } & WG & 89.877 & 39 & 2.305 & & \\
\cline { 2 - 7 } & Total & 117.905 & 41 & & & \\
\hline \multirow{3}{*}{ EAM-BH } & BG & 2.403 & 2 & 1.202 & 3.905 & $.028^{*}$ \\
\cline { 2 - 7 } & WG & 12.002 & 39 & .308 & & \\
\cline { 2 - 7 } & Total & 14.405 & 41 & & & \\
\hline \multirow{3}{*}{ GM-BH } & BG & 1.116 & 2 & .558 & 2.186 & .126 \\
\cline { 2 - 7 } & WG & 9.955 & 39 & .255 & & \\
\cline { 2 - 7 } & Total & 11.071 & 41 & & & \\
\hline
\end{tabular}

${ }^{*} p<.05$, one-way ANOVA.

\subsection{2. 연령별 외이도에서 설골까지의 거리 비교}

연령별 설골 위치를 비교해 보기 위해 X-ray 촬영 후 정상 아 동들의 경추측면촬영영상의 랜드마크(표지점)인 $\mathrm{EAM}$ 에서 설 골까지의 거리를 측정하여 비교분석 하였다. 그 결과, 4 세 아동 
의 $\mathrm{EAM}$ 에서 설골까지의 거리 $(6.71, \pm 0.73)$ 가 가장 긴 것으로 나 타났으며(표 2), 그 다음으로 3세 아동의 EAM에서 설골까지의 거리(6.47 \pm 0.51$)$ 가 두 번째로 길었고, 2 세 아동의 $\mathrm{EAM}$ 에서 $\mathrm{BH}$

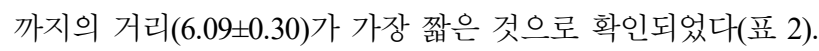
연령별 $\mathrm{EAM}$ 에서 $\mathrm{BH}$ 까지의 거리를 비교해 본 결과, 연령 간에 $\mathrm{EAM}$ 에서 $\mathrm{BH}$ 까지 거리가 통계학적으로 유의미하게 차이가 있 는 것으로 나타났다 $(p<.05$, 표 3$)$.

$\mathrm{EAM}$ 와 $\mathrm{BH}$ 간의 거리가 연령 별로 어떠한 차이가 있는지 사 후검정을 실시해 본 결과, 설골 높이와 달리 2세와 4세간에 $\mathrm{EAM}$ 과 $\mathrm{BH}$ 간의 거리가 통계학적으로 유의미하게 차이가 있는 것으로 확인되었다 $(p<.05$, 표 4). 반면 2세와 3 세 간의 EAM과 $\mathrm{BH}$ 간의 거리는 통계학적인 차이가 없는 것으로 나타났으며(표 4), 3 세와 4세 간의 EAM과 $\mathrm{BH}$ 간의 거리도 유의미한 차이가 없 는 것으로 나타났다(표 4).

표 4. 정상 아동의 연령별 후두 차이에 대한 다중 비교 Table 4. Multiple comparisons of laryngeal height in normal

\begin{tabular}{|c|c|c|c|c|c|c|}
\hline Domain & (I) age & (J) age & $\begin{array}{c}\text { Mean } \\
\text { difference } \\
(I-J)\end{array}$ & Std. error & Sig. & $\begin{array}{l}\text { Upper } \\
\text { bound }\end{array}$ \\
\hline \multirow{9}{*}{$\mathrm{BH}$} & \multirow{3}{*}{2} & 2 & & & & \\
\hline & & 3 & $-2.048^{*}$ & .639 & .011 & -.42 \\
\hline & & 4 & -1.279 & .487 & .054 & .02 \\
\hline & \multirow{3}{*}{3} & 2 & $2.048^{*}$ & .639 & .011 & 3.68 \\
\hline & & 3 & & & & \\
\hline & & 4 & .769 & .521 & .385 & 2.11 \\
\hline & \multirow{3}{*}{4} & 2 & 1.279 & .487 & .054 & 2.58 \\
\hline & & 3 & -.769 & .521 & .385 & .57 \\
\hline & & 4 & & & & \\
\hline \multirow{9}{*}{$\begin{array}{c}\text { EAM- } \\
\text { BH } \\
(\mathrm{cm})\end{array}$} & \multirow{3}{*}{2} & 2 & & & & \\
\hline & & 3 & -.380 & .154 & 0.60 & .01 \\
\hline & & 4 & $-.623^{*}$ & .214 & .027 & -.06 \\
\hline & \multirow{3}{*}{3} & 2 & .380 & .154 & .060 & .77 \\
\hline & & 3 & & & & \\
\hline & & 4 & -.244 & .231 & .649 & .35 \\
\hline & \multirow{3}{*}{4} & 2 & $.623^{*}$ & .214 & .027 & 1.18 \\
\hline & & 3 & .244 & .231 & .649 & .84 \\
\hline & & 4 & & & & \\
\hline \multirow{9}{*}{$\begin{array}{l}\text { GM- } \\
\text { BH } \\
(\mathrm{cm})\end{array}$} & \multirow{3}{*}{2} & 2 & & & & \\
\hline & & 3 & .321 & .153 & .129 & .71 \\
\hline & & 4 & -.019 & .188 & .999 & .47 \\
\hline & \multirow{3}{*}{3} & 2 & -.321 & .153 & .129 & .07 \\
\hline & & 3 & & & & \\
\hline & & 4 & -.340 & .205 & .288 & .18 \\
\hline & \multirow{3}{*}{4} & 2 & .019 & .188 & .999 & .51 \\
\hline & & 3 & .340 & .205 & .288 & .86 \\
\hline & & 4 & & & & \\
\hline
\end{tabular}

${ }^{*} p<.05$, Dunnett T3 multiple comparison.

\subsection{3. 연령별 하악끝점에서 설골까지의 거리 비교}

X-ray 촬영 후 연령별 정상 아동의 설골 높이를 비교해 보기 위해, 경추측면 촬영 영상의 또 다른 랜드마크(표지점)인 $\mathrm{GM}$ 에 서 $\mathrm{BH}$ 까지의 거리를 측정하여 비교해 본 결과, 2세의 $\mathrm{GM}$ 에서 $\mathrm{BH}$ 까지의 거리 $(1.91 \pm 0.30)$ 와 4 세의 $\mathrm{GM}$ 에서 $\mathrm{BH}$ 까지의 거리 (1.93 \pm 0.62$)$ 가 3 세 $(1.59 \pm 0.51)$ 세보다 긴 것으로 확인되었다. 하지
만 연령 간의 $\mathrm{GM}$ 에서 $\mathrm{BH}$ 까지의 거리는 통계적으로 유의미한 차이가 나타나지 않았다(표 3 , 표 4).

그림 1은 2 4세 정상 대조군 아동들과 4세 ASD 아동의 측면 경추 X-ray 사진으로, 정상 대조군 아동들의 연령별 후두 위치 와 4세 ASD 아동의 후두 위치를 확인할 수 있다.

\subsection{ASD 아동의 연령별 후두 위치 비교}

\subsection{1. 연령별 설골의 높이 비교}

$\mathrm{ASD}$ 아동의 연령별 설골의 높이를 비교하기 위해 X-ray 촬영 후 $\mathrm{ASD}$ 아동들의 $\mathrm{BH}$ 상단 높이를 경추 높이와 비교하였다. 그

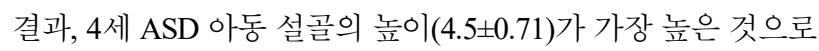
나타났으며, 2 세 아동의 설골 높이 $(5 \pm 0)$ 와 3 세 아동의 설골 높 이 $(5 \pm 0.82)$ 는 두 연령 모두 평균 5점으로 평가되어, 4 세 ASD 아 동의 설골 높이보다 낮은 것으로 확인되었다(표 5).

표 5. $\mathrm{ASD}$ 아동의 연령별 후두 위치 측정 결과 Table 5. Measurement results of laryngeal height in ASD

\begin{tabular}{c|c|c|c|c|c|c|c}
\hline & Age & No. & Mean & $S D$ & Std. error & $\begin{array}{c}\text { Lower } \\
\text { bound }\end{array}$ & $\begin{array}{c}\text { Upper } \\
\text { bound }\end{array}$ \\
\hline \multirow{3}{*}{ BH } & 2 & 2 & 5 & 0 & 0 & 5 & 5 \\
\cline { 2 - 8 } & 3 & 4 & 5 & 0.82 & 0.41 & 4 & 6 \\
\cline { 2 - 8 } & 4 & 2 & 4.5 & 0.71 & 0.5 & 4 & 5 \\
\hline \multirow{2}{*}{ EAM- } & 2 & 2 & 5.91 & 0.40 & 0.29 & 5.62 & 6.19 \\
\cline { 2 - 8 } BH & 3 & 4 & 6.56 & 0.65 & 0.32 & 5.84 & 7.39 \\
\cline { 2 - 8 } & 4 & 2 & 6.48 & 0.93 & 0.66 & 5.82 & 7.14 \\
\hline \multirow{2}{*}{ GM- } & 2 & 2 & 3.16 & 0.54 & 0.39 & 2.77 & 3.54 \\
\cline { 2 - 8 } BH & 3 & 4 & 3.09 & 1.24 & 0.28 & 2.28 & 3.52 \\
\cline { 2 - 8 } & 4 & 2 & 3.04 & 0.10 & 0.07 & 2.97 & 3.11 \\
\hline
\end{tabular}

ASD, autism spectrum disorders; $\mathrm{BH}$, body of hyoid bone; EAM, external acoustic meatus; GM, gonion of mandible.

\subsection{2. 연령별 외이도에서 설골까지의 거리 비교}

$\mathrm{X}$-ray 촬영 후 $\mathrm{ASD}$ 아동의 $\mathrm{EAM}$ 에서 $\mathrm{BH}$ 사이의 거리를 비교

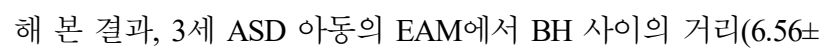
0.65 )가 가장 길었고, 4 세 아동의 $\mathrm{EAM}$ 에서 $\mathrm{BH}$ 사이의 거리 (6.48 \pm 0.93$)$ 가 그 다음으로 길었으며, 2세 아동의 EAM에서 $\mathrm{BH}$ 사이의 거리(5.91 \pm 0.40$)$ 가 가장 짧은 것으로 평가되었다(표 5). 이 결과를 정상 대조군과 비교해 보면, $\mathrm{ASD}$ 아동과 정상 대조 군 아동의 $\mathrm{EAM}$ 에서 $\mathrm{BH}$ 사이 거리는 공통적으로 2 세가 가장 짧 았다. 또한, 정상 대조군 아동의 $\mathrm{EAM}$ 에서 $\mathrm{BH}$ 사이의 거리는 4 세가 가장 길었으나, $\mathrm{ASD}$ 아동의 $\mathrm{EAM}$ 에서 $\mathrm{BH}$ 사이의 거리는 3 세가 가장 긴 것으로 측정되었다(표 5).

\subsection{3. 연령별 하악끝점에서 설골까지의 거리 비교}

X-ray 촬영 후 $\mathrm{ASD}$ 아동의 $\mathrm{GM}$ 에서 $\mathrm{BH}$ 사이의 거리를 비교 해 본 결과, 2 세 $\mathrm{ASD}$ 아동의 $\mathrm{GM}$ 에서 $\mathrm{BH}$ 사이의 거리(3.16 0.54 )가 가장 길었고, 3 세 아동의 $\mathrm{GM}$ 에서 $\mathrm{BH}$ 사이의 거리 $(3.09 \pm 1.24)$ 는 그 다음으로 길었으며, 4 세 아동의 $\mathrm{GM}$ 에서 $\mathrm{BH}$ 사이의 거리(3.04 \pm 0.10$)$ 가 가장 짧은 것으로 평가되었다(표 5). 


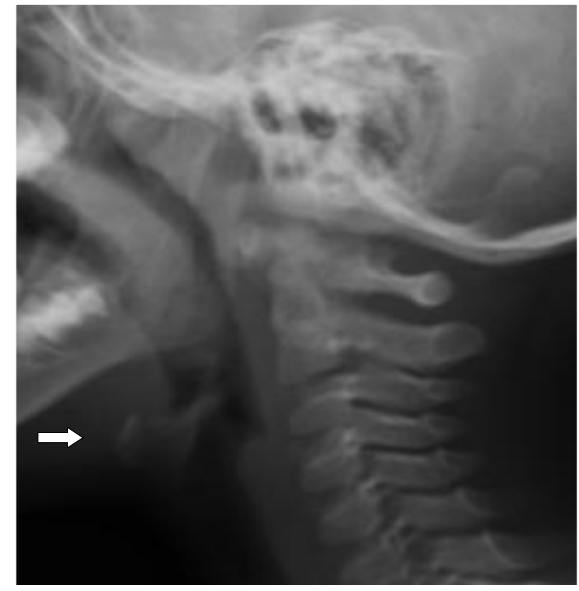

(1) 정상 아동 2 세

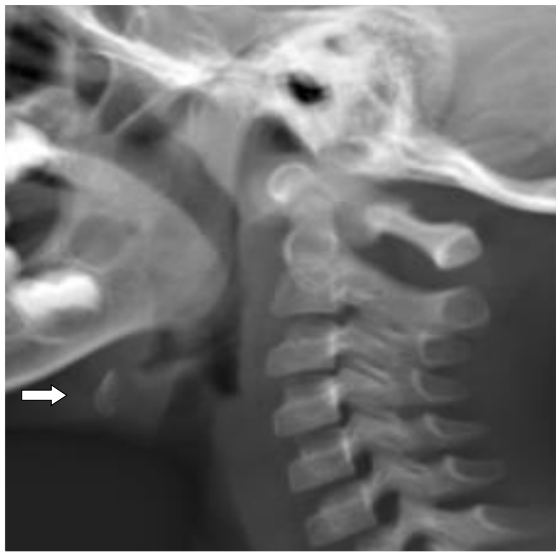

(3) 정상 아동 4 세

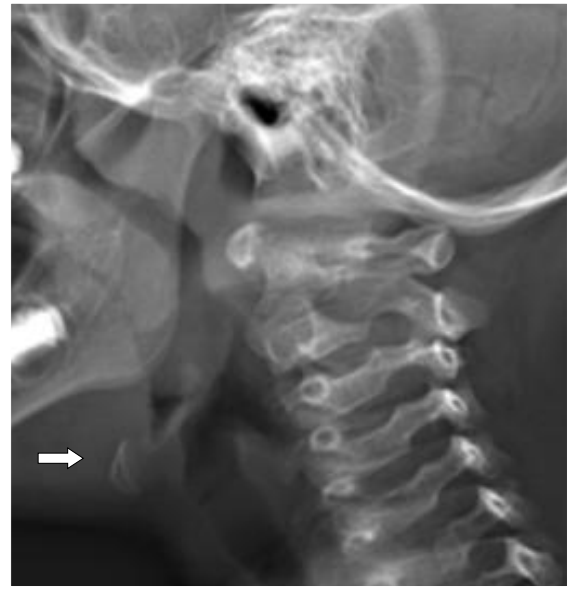

(2) 정상 아동 3 세

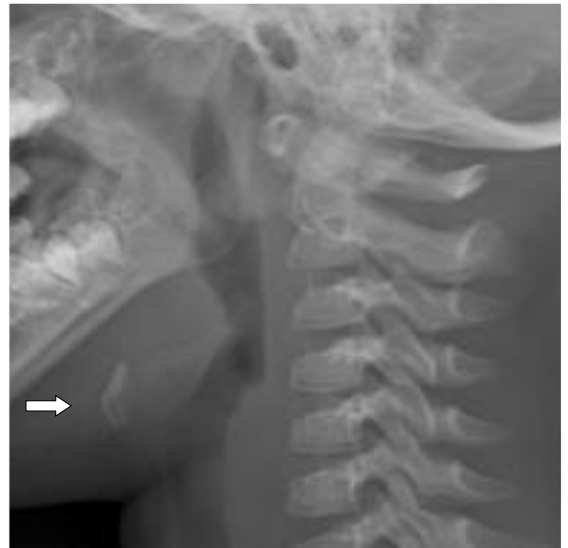

(4) $\mathrm{ASD}$ 아동 4 세

그림 1. 연령대별 측면 경추 X-ray 소견

Figure 1. Lateral cervical X-ray findings by age

3.3. $\mathrm{ASD}$ 와 정상 아동 간의 연령별 후두 위치 차이점

이 결과들을 $\mathrm{ASD}$ 군과 정상군을 비교해 보면, 정상 대조군 아 동의 $\mathrm{GM}$ 에서 $\mathrm{BH}$ 사이의 거리는 4 세가 가장 길었던 것에 비하 여 $\mathrm{ASD}$ 아동의 $\mathrm{GM}$ 에서 $\mathrm{BH}$ 사이의 거리는 4 세가 가장 짧은 것 으로 평가되었다. 그리고, $\mathrm{ASD}$ 아동과 정상 대조군 아동 모두 2 세의 $\mathrm{GM}$ 에서 $\mathrm{BH}$ 사이의 거리가 3 세의 $\mathrm{GM}$ 에서 $\mathrm{BH}$ 사이의 거 리보다 더 긴 것으로 나타났다(표 5). 물론, 앞에서의 결과와 마 찬가지로 실험에 참가한 $\mathrm{ASD}$ 아동의 수가 적어 통계적 유의성 은 확인할 수 없었다.

3.4. ASD 와 정상 아동 간 모음 발성 시 음향학적 변수의 차이점

$\mathrm{ASD}$ 아동들과 정상 아동 간의 모음 연장 발성 시 음향학적 변수들을 비교해 본 결과, 기본주파수범위 세미톤(PFR)은 ASD 군이 정상 대조군에 비해 통계학적으로 유의미하게 높은 것으 로 나타났다 $(p<.05$, 표 6). 그러나 기본주파수 $(\mathrm{Fo})$, 최대기본주파 수(Fhi), 최소기본주파수(Flo) 등은 두 군간 유의미한 차이가 없 는 것으로 확인되었다.

$\mathrm{ASD}$ 아동들과 정상 대조군간의 모음 연장 발성 시 음질 변수 들을 비교해 본 결과, 주파수 변동율(jitter), 진폭 변동율(shimmer)
그리고 소음관련 변수(NHR, VTI, SPI) 등은 두 군간 통계적으로 유의미한 차이가 없는 것으로 확인되었다(표 6)

표 6. 음향학적 변수들의 특징 비교

Table 6. Comparisons of acoustic parameters during vowel phonation

\begin{tabular}{c|c|c|c|c}
\hline \multirow{2}{*}{$\begin{array}{c}\text { Para- } \\
\text { meter }\end{array}$} & ASD group $(\mathrm{n}=6)$ & $\begin{array}{c}\text { Control group } \\
(\mathrm{n}=11)\end{array}$ & \multirow{2}{*}{ z-value } & p-value \\
\cline { 2 - 5 } & $\mathrm{M} \pm \mathrm{SD}$ & $\mathrm{M} \pm \mathrm{SD}$ & & \\
\hline Fo & $286.8 \pm 25.8$ & $272.3 \pm 28.5$ & -1.207 & .256 \\
\hline Fhi & $332.4 \pm 54.5$ & $282.2 \pm 31.1$ & -1.709 & .098 \\
\hline Flo & $258.3 \pm 19.8$ & $264.8 \pm 25.4$ & -.326 & .792 \\
\hline PFR & $5.5 \pm 2.6$ & $2.5 \pm 0.5$ & $-3.208^{*}$ & .001 \\
\hline Jitter & $1.718 \pm 0.872$ & $1.101 \pm 1.015$ & -1.532 & .180 \\
\hline Shimmer & $5.630 \pm 1.694$ & $4.122 \pm 1.587$ & -1.712 & .098 \\
\hline NHR & $0.158 \pm 0.044$ & $0.116 \pm 0.012$ & .000 & 1.000 \\
\hline SPI & $2.827 \pm 1.74$ & $3.808 \pm 3.773$ & -.051 & .961 \\
\hline VTI & $0.076 \pm 0.039$ & $0.065 \pm 0.020$ & .000 & 1.000 \\
\hline vFo & $3.793 \pm 1.486$ & $1.354 \pm 0.656$ & $-3.280^{*}$ & .000 \\
\hline vAm & $22.675 \pm 8.810$ & $7.639 \pm 1.872$ & $-3.341^{*}$ & .000 \\
\hline
\end{tabular}

${ }^{*} p<.05, \mathrm{Z}$ values on Mann-Whitey U test.

ASD: autism spectrum disorders.

$\mathrm{ASD}$ 아동들과 정상 대조군간의 모음 연장 발성 시 $\mathrm{vFo}$ 와 $\mathrm{vAm}$ 을 비교해 본 결과, $\mathrm{ASD}$ 아동들이 정상 대조군에 비해 $\mathrm{vFo}$ 
와 vAm이 통계학적으로 유의미하게 높은 것으로 나타났다 $(p<.05$, 표 6).

\section{4. 논의}

본 연구는 $\mathrm{ASD}$ 아동들의 후두 양상과 음향학적 특성을 알아 보기 위해서 2 4세 정상 대조군 아동들의 경추 대비 $\mathrm{BH}$ 상단의 높이, $\mathrm{EAM}$ 에서 $\mathrm{BH}$ 상단까지의 거리, $\mathrm{GM}$ 에서 $\mathrm{BH}$ 상단까지의 거리를 측정하고 그 결과를 $\mathrm{ASD}$ 아동들과 비교하였다. 또한 음 성분석을 통해서 정상 대조군 아동과 $\mathrm{ASD}$ 아동의 음향학적 파 라미터들을 함께 비교분석 하였으며, 그 결과는 다음과 같다. 첫째, 정상아동들의 경우 3 세의 설골 높이가 2 세의 설골 높이보 다 낮았지만, 4세의 설골 높이는 3 세보다도 높았다. 또한, 4세 아동의 EAM에서 설골까지 거리는 3 세 아동의 EAM에서 설골 까지 거리보다 길었다. 3 세 아동의 설골 높이가 2 세 아동에 비 해서 낮아졌다는 것은 발달에 따른 후두의 하강을 의미하며, Laitman et al.(1977)도 1세 영유아 갑상연골의 상단과 하단은 각 각 $\mathrm{C} 1$ 과 $\mathrm{C} 4$ 높이에 위치하였다가, 2 세 전후로 후두가 하강하기 시작하면서 7세가 되면 C3 와 C5 높이에 위치하게 된다고 보고 하였다(Lieberman, 1984; Sasaki et al., 1977).

본 실험에서 3 세 아동의 설골 높이가 2 세 아동의 설골 높이보 다 더 낮은 결과가 나온 것은 Laitman et al.(1977)의 연구와 정확 하게 일치한다. 물론, 기존의 연구자들은 본 연구와는 달리 영유 아 카데바(cadaver; 해부용 시신)에서 갑상연골(thyroid cartilage) 의 경추 대비 높이를 측정하여 보고하였지만, 2 세를 전후하여 후두가 하강된다는 결과는 두 연구가 일치하였다. 본 연구에서 X-ray를 사용하여 설골(hyoid bone)을 촬영한 이유는 후두연골의 골화가 매우 서서히 진행되어, X-ray 촬영을 통해서는 영유아의 갑상연골 형태를 정확하게 알 수 없기 때문이었다(Türkmen et al., 2012).

본 연구 결과에서 주목할 만한 사실은 4세 아동의 설골 높이 가 3 세 아동의 설골 높이보다 오히려 더 높아진 것으로 확인되 었다는 것이다. 이와 같은 현상은 4세 아동의 언어발달 특징과 연관이 있을 것으로 사료된다. 4세 아동의 언어발달은 ‘구문-문 법적 이해기'를 거치면서 3 세 아동에 비해 문장 사용이 양적, 질 적으로 매우 많아진다. 뿐만 아니라, 평균발화 길이(mean length of utternace, MLU)도 매우 길어져서 4 8개 낱말로 구성된 문장 의 사용이 증가하며, $900 ~ 2,000$ 개의 표현어휘를 습득하고, 분당 185 개 낱말 정도를 말할 수 있게 된다고 보고하였다(Kim, 2014). 특히, 더듬는 횟수가 줄어들며 $90 \%$ 정도의 자음 정확도를 획득 하고, 자주 나타내던 생략이나 대치와 같은 조음 오류도 많이 줄어들게 된다고 보고하였다. 이와 같은 폭발적인 언어발달을 가져오는 4세 시기가 상대적으로 표현어휘 사용 빈도가 적은 3 세에 비해 후두 높이가 오히려 높아지는 것으로 생각되어진다.

또한, 4세 아동 EAM에서 설골까지 거리는 3세 아동 EAM에 서 설골까지 거리보다 길었다(표 2). 이는 후두가 위로 상승하면 서 전방화(anteriorization) 되었기 때문에 나타난 결과로 해석된 다. 이 결과도 3 세 아동에 비해 폭발적인 언어사용을 보이는 4
세 아동의 언어발달 시기와 관련이 있을 것으로 사료된다.

설골과 혀의 상승은 삼차신경(Trigeminal Nerve, $\mathrm{CN} \mathrm{V}$ )의 지 배를 받는 악설골근(mylohyoid muscle)의 수축으로 이루어지고, 설골과 후두의 상승은 설하신경(hypoglossal nerve, CN XII)의 지배 를 받는 이설골근(geniohyoid muscle)과 삼차신경 $(\mathrm{CN} \mathrm{V})$ 과 안면 신경(facial nerve: $\mathrm{CN}$ VII)의 지배를 받는 이복근(digastric muscle $5,7)$, 안면신경(CN VI)의 지배를 받는 경상설골근(stylohyoid muscle)의 수축으로 이루어진다.

설골의 상승은 설하신경 $(\mathrm{CN} \mathrm{XII)}$ 의 지배를 받는 설하근(hyoglossus muscle)과 갑상설골근(thyrohyoid muscle)의 수축으로 이루어진 다. 또한 후두의 상승은 부신경(accessory nerve, CN IX)의 지배 를 받는 경상인두근(stylopharyngeus muscle)의 수축으로 이루어 지며 혀의 수축은 설하신경(CN XI)의 지배를 받는 이설근(genioglossus muscle)의 수축으로 이루어진다(Jeong, 2003; Johnson-Root, 2015; Logemann, 1998; Seikel et al., 2013).

4세 아동처럼 후두가 상승하고 전방화 되면 조음자(혀)와 조 음점(치조, 경구개, 입술 등)의 거리가 더 가까워지게 된다. 이렇 게 조음자와 조음점의 거리가 좀 더 가까워지게 되면 조음이 훨 씬 쉽고 빠르게 이루어질 수 있으며, 이로 인해서 조음의 명료 도도 상승하고 유창성도 더 잘 획득될 수 있다. 이것은 4세의 폭 발적인 언어발달과 연관이 있을 것으로 사료된다. 이러한 후두 의 상승과 전방화로 여겨지는 $\mathrm{BH}$ 의 상승과 $\mathrm{EAM}$ 에서 $\mathrm{BH}$ 거리 의 유의미한 증가는 4세 아이들의 언어 발달 특성과도 연관이 있을 것으로 사료된다.

두번째 결과로, 2 세와 3 세, 그리고 4세 ASD 아동의 설골 높이 가 전 연령의 정상 대조군 아동 설골 높이보다 낮게 위치하고 있는 것으로 확인되었다. 또한 $\mathrm{ASD}$ 아동의 $\mathrm{EAM}$ 에서 $\mathrm{BH}$ 까지 의 거리는 연령 간 유의미한 차이가 발견되지 않았다. 이것은 $\mathrm{ASD}$ 아동들의 설골 상승 및 전방화가 정상적으로 이루어지지 않았을 가능성을 시사하는 것으로 사료되며, 아마도 ASD 아동 들이 겪고 있는 언어발달 지연과 관련이 있는 것으로 사료된다.

후두 높이의 차이는 다양한 주변 근육조직 및 운동 기전에 영 향으로 발생한다. Shipp \& Izdebski(1975)는 발성을 하게 되면 후 두 외근들의 수축작용으로 인해서 후두가 위로 상승하는 동시 에 앞쪽으로 이동하게 된다고 보고하였고, 발성 시 후두의 상승 은 갑상설골근(thyrohyoid muscle)의 수축 작용과 밀접하게 연관 이 되어 있다고 보고한 바 있다(Shipp, 1975). 결과적으로 ASD 아동들의 낮아진 설골 높이는 정상 아동들에 비해 발성 시 적절 한 후두 높이를 유지하는데 불리하게 작용할 것으로 사료된다.

특히, 후두의 상승은 음도의 상승과 관련이 있으며, 후두의 하강은 저음 산출에 용이하다고 보고한 바 있다(Shipp, 1975). ASD 아동은 음도 변화가 적은 음성을 사용하며(Kanner, 1943), 이는 $\mathrm{ASD}$ 아동의 제한적인 운율 사용을 나타낸다. 본 연구에서 도 확인되었듯이 $\mathrm{ASD}$ 아동의 후두 높이가 정상 대조군에 비해 낮아져 있으며, 이는 $\mathrm{ASD}$ 아동의 제한적인 운율 사용과도 관련 성이 있는지 후속 연구를 통해 조사해 볼 필요가 있을 것이라 사료된다.

또한 정상 대조군 아동들의 설골 높이는 2 세, 4 세, 3 세 순으로 
높았었던 것과 다르게, $\mathrm{ASD}$ 아동들의 설골 높이는 4세가 가장 높았고, 2 세와 3 세는 같았다. 흥미로운 점은 $\mathrm{ASD}$ 아동의 설골 높이도 정상 대조군 아동처럼 3 세보다 4세가 더 높았다는 것이 다. 물론, 실험에 참가한 $\mathrm{ASD}$ 아동의 수가 적어 통계적 유의성 은 확인할 수 없었다.

실험 초기에는 연령별 $\mathrm{ASD}$ 아동 수가 5명씩 계획되었으나 실험에 대한 거부와 건강 등의 원인으로 인해서 총 8 명의 $\mathrm{ASD}$ 아동만이 최종적으로 실험에 참가할 수 있었기 때문이다. 참고 로, 8 명 중 1 명(S2)을 제외한 나머지 7명의 참가자 모두 무발화 $\mathrm{ASD}$ 아동들이었으며, 다행스럽게도 대부분 발성은 활발한 편 이라 실험을 진행할 수 있었다.

이와 같이, $\mathrm{ASD}$ 아동의 $\mathrm{EAM}$ 에서 $\mathrm{BH}$ 사이 거리는 정상 대조 군 아동과 다르게 연령 간 유의미한 차이가 나타나지 않았다. 이는 후두의 상승과 전방화가 되지 않았다는 것을 의미하는데, 언어발달이 제한되어 있는 $\mathrm{ASD}$ 아동의 후두는 연령이 증가함 에도 불구하고 상승이나 전방화와 같은 다이나믹한 변화가 일 어나지 않는다는 것을 의미한다. 또한 설골 높이가 연령이 증가 함에도 불구하고 정상 대조군 아동과 다르게 일정했었던 것과 마찬가지로, $\mathrm{EAM}$ 에서 $\mathrm{BH}$ 사이 거리가 정상 대조군 아동과 다 르게 연령 간 유의미한 차이가 나타나지 않았다는 것은 ASD 아 동의 언어발달지연을 확인할 수 있는 중요한 지표라고 판단된 다. 물론, 실험에 참가한 $\mathrm{ASD}$ 아동의 수가 적어 통계적 유의성 은 확인할 수 없었다.

특히, 모음 발성 시 음질은 실험 결과에서 보듯이 쉰목소리 정도를 평가하는 대표적 변수인 jitter, shimmer, NHR 값이 정상 대조군과 차이가 없는 정상 범주로 나타나 정상대조군과 차이 를 보인 조절 변수들(PFR, $\mathrm{vFo}, \mathrm{vAm})$ 과는 다른 양상을 보인 점 도 주목할만한 결과로 보인다.

음향학적 평가 결과, $\mathrm{ASD}$ 가 정상 아동에 비해 음질유지 능력 을 나타내는 변화량 변수(PFR, $\mathrm{vFo}, \mathrm{vAm})$ 에 조절 문제가 있는 것으로 확인되었는데 최근 선행 연구에서도 같은 결과를 보고 한 바 있다. Lee et al.(2020)은 자폐성 정도가 각기 다르며, 언어 발달 점수가 다양한 10 명의 $\mathrm{ASD}$ 아동들과 동일 연령대의 정상 대조군 10 명을 대상으로 모음 /a/ 연장 발성 시 음성을 분석하여 비교해 본 결과, 주파수 관련 변수들 중 넓은 구간의 기본주파 수 변동률을 측정하는 PFR에서 통계학적으로 유의미한 차이를 발견하였으며, jitter, shimmer와 같은 음질의 중요한 변수들은 모두 정상 대조군과 차이가 없는 것을 확인하였다. 또한, 발성 시 주파수변화량과 진폭변화량 변수인 $\mathrm{vFo}$ 와 $\mathrm{vAm}$ 이 정상 아동 들에 비해 ASD 아동들이 통계학적으로 유의미하게 높은 것으 로 나타났으며, 본 연구와 일치하는 결과를 확인하였다. 이는 $\mathrm{ASD}$ 아동의 경우, 모음 발성 시 성대 진동을 포함한 발성에 관 여하는 후두 내외근의 안정성을 유지하지 못하고 조절에 실패 한 결과로 해석된다.

$\mathrm{ASD}$ 아동이 모음 발성 시 $\mathrm{PFR}, \mathrm{vFo}, \mathrm{vAm}$ 값이 정상 아동보다 높다는 것은 발성기관에 대한 조절능력(phonatory control)의 어 려움을 나타내는 지표로 사료되며, 이 지표는 이전의 많은 연구 들에서도 확인할 수 있었다(Kent et al., 1999; Kent et al., 2000).
특히, Kent et al.(1999)의 연구에서는 다양한 마비말장애 환자들 이 보이는 조절능력 부재를 나타내는 지표로 PFR, vFo, vAm을 제시하였으며, 이는 본 연구결과와 일치하는 지표로서, $\mathrm{ASD}$ 아 동의 뇌신경발달 문제(neurogenic developmental problem)를 간 접적으로 시사하는 결과로 해석될 수 있어 향후 이에 대한 검증 이 필요할 것으로 사료된다.

본 연구의 제한점으로, ASD 대상자 수가 적어 통계학적인 해 석이 어려운 점을 들 수 있다. 실험과정에서 실패율이 매우 높 은 대상임을 감안하여 많은 수의 ASD 아동을 실험군에 포함할 필요가 있다. 또한 5세 이후 ASD 아동의 후두 특성도 확인할 필 요가 있을 것으로 사료되며, 후속 연구에서는 ASD 아동의 후두 위치 및 발성 능력을 개선시킬 수 있는 치료법에 대한 연구가 필요할 것으로 사료되어 이를 제언한다.

\section{5. 결론}

X-ray 촬영을 통한 후두 위치 측정 실험을 통해 아동들의 후 두 위치를 평가한 결과, 정상군에서는 3 세 아동에 비해 폭발적 인 언어발달을 보이는 4세 아동의 경우, 후두 높이가 상승하고 전방화되는 반면, $\mathrm{ASD}$ 아동은 연령에 관계없이 낮게 위치하는 후두 특성을 보인다. 또한 두 군의 모음 발성 시 음성 변수들을 비교한 결과, 음성 조절 기능을 보여주는 $\mathrm{PFR}, \mathrm{vFo}, \mathrm{vAm}$ 이 정상 아동과 $\mathrm{ASD}$ 아동의 음질 차이를 보여주는 voice marker로 사료 된다.

\section{References}

Adolphs, R., Sears, L., \& Piven, J. (2001). Abnormal processing of social information from faces in autism. Journal of Cognitive Neuroscience, 13(2), 232-240.

American Psychiatric Association. (2013). Diagnostic and statistical manual of mental disorders (5th ed.). Washington, DC: APA Press.

Baltaxe, C. A. (1981). Acoustic characteristics of prosody in autism. International congress for the scientific study of mental deficiency. In P. Mittler (Ed.), New frontiers of knowledge in the scientific study of mental deficiency (pp. 223-233). Baltimore, MD: University Park.

Benninger, M. S., Murry, T., \& Johns M. M. III, (2016). The performer's voice (2nd ed.). San Diego, CA: Plural.

Bontrager, K. L., \& Lampignano, J. (2005). Textbook of radiographic positioning and related anatomy (6th ed.). St. Louis, MO: Elsevier.

Bregman, J. D. (2005). Definitions and characteristics of the spectrum. In D. Zager (Ed.), Autism spectrum disorders: Identification, education, and treatment (3rd ed., pp. 3-46). Mahwah, NJ: Lawrence Erlbaum Associates.

Ferrand, C. T. (2011). Speech science: An integrated approach to theory and clinical practice. Boston, MA: Allyn \& Bacon.

Freed, D. B. (2012). Motor speech disorder, diagnosis and treatment 
(2nd ed.). Clifton Park, NY: Delmar/Cengage Learning.

Jo, K. J., \& Kim, J. K. (2011). The relationship between autistic features and empathizing-systemizing traits. Science of Emotion \& Sensibility, 14(2), 245-256.

Johnson-Root, B. A. (2015). Oral-facial evaluation for speechlanguage pathologists. San Diego, CA: Plural Publishing.

Jung, K. S., \& Seong, C. J. Comparison of prosody characteristics in sentence reading of children with autism spectrum disorder and normal children. Communication Sciences \& Disorders, 12(4), 625-642.

Jeong, O. R. (2003). Speech pathology anatomy, Pusan: Korean Speech-language \& Hearning Association.

Kanner, L. (1943). Autistic disturbances of affective contact. Nervous Child: Journal of Psychopathology, Psychotherapy, Mental Hygiene, and Guidance of the Child 2, 217-250.

Kanner, L. (1971). Follow-up study of eleven autistic children originally reported in 1943. Journal of Autism and Childhood Schizophrenia, 1(2), 119-145.

Kent, R. D., Kent, J. F., Duffy, J. R., Thomas, J. E., Weismer, G., \& Stuntebeck, S. (2000). Ataxic dysarthria. Journal of Speech, Language, and Hearing Research, 43(5), 1275-1289.

Kent, R. D., Vorperian, H. K., \& Duffy, J. R. (1999). Reliability of the multi-dimensional voice program for the analysis of voice samples of subjects with dysarthria. American Journal of Speech-Language Pathology, 8(2), 129-136.

Kim, B. N., Kim, J. W., Kwon, M. K., Youn, S. A., Kang, T. W., \& Han, I. W. (2017). Autism parent education. Seoul, Korea: Hakjisa.

Kim, Y. T. (2014). Diagnosis and treatment of language disorders in children (2nd ed.). Seoul, Korea: Hakjisa.

Kwon, J. A. (2014). A study on the diagnosis of autism spectrum disorder in DSM-5 through the history of the concept of autism: Focusing on PDD-NOS, Soonchunhyang Journal of Humanities, 34(1), 101-130.

Laitman, J. T., \& Crelin, E. S. (1976). Postnatal development of the basicranium and vocal tract region in man. In J. F. Bosma (Ed.), Symposium on the development of the basicranium (pp. 206-219). Washington, DC: US Government Printing Office.

Laitman, J. T., \& Reidenberg, J. S. (1993). Comparative and developmental anatomy of laryngeal position. In B. Bailey (Ed.), Head and neck surgery-otolaryngology (pp. 36-43). Philadelphia, PA: Lippincott.

Laitman, J. T., Crelin, E. S., \& Conlogue, G. J. (1977). The function of the epiglottis in monkey and man. Yale Journal of Biology and Medicine, 50(1), 43-48.

LaPointe, L. L., Murdoch, B. E., \& Stierwalt, J. A. G. (2010). Brain-based communication disorders. San Diego, CA: Plural.

Lee, J. H., Kim, K. U., Kim, S. T. (2020). Characteristics of voice in children with autism spectrum disorders, Journal of Rehabilitation
Welfare Engineering \& Assistive Technology, 14(3), 195-202.

Lieberman, P. (1984). The biology and evolution of language. Cambridge, MA: Harvard University Press.

Lieberman, P., Kako, E., Friedman, J., Tajchman, G., Feldman, L. S., \& Jiminez, E. B. (1992). Speech production, syntax comprehension, and cognitive deficits in Parkinson's desease. Brain and Language, 43(2), 169-189.

Logemann, J. A. (1998). The Evaluation and treatment of swallowing disorders (2nd ed.). Austin, TX: Pro-Ed.

Magriples, U., \& Laitman, J. T. (1987). Developmental change in the position of the fetal human larynx. American Journal of Physical Anthropology, 72(4), 463-472.

Mayes, S. D., Black, A., \& Tierney, C. D. (2013). DSM-5 underidentifies PDDNOS: Diagnostic agreement between the DSM-5, DSM-IV, and checklist for autism spectrum disorder. Research in Autism Spectrum Disorders, 7(2), 298-306.

Nakai, Y., Takashima, R., Takiguchi, R., \& Takada, S. (2014). Speech intonation in children with autism spectrum disorder. Brain and Development, 36(6), 516-522.

Paul, R., Augustyn, A., Klin, A., \& Volkmar, F. R. (2005). Perception and production of prosody by speakers with autism spectrum disorders. Journal of Autism and Developmental Disorders, 35(2), 205-220

Sasaki, C. T., Levine, P. A., Laitman, J. T., \& Crelin, E. S. (1977). Postnatal descent of the epiglottis in man. A preliminary report. Archives of Otolaryngology, 103(3), 169-171.

Sataloff, R. T. (2005). Voice science. San Diego, CA: Plural.

Seikel. J. A., Drumright, D. G., \& Seikel, P. (2013). Essentials of anatomy \& physiology (4th ed.). Boston, MA: Cengage Learning.

Shipp, T., (1975). Vertical laryngeal position during continuous and discrete vocal frequency change. Journal of Speech, Language, and Hearing Research, December, 18(4), 707-718.

Shipp, T., \& Izdebski, K. (1975). Vocal frequency and vertical larynx positioning by singers and nonsingers. Journal of Acoustical Society of America, 58(5), 1104-1106.

Smerbeck, A. M. (2015). Nasal voice in boys with high-functioning autism spectrum disorder. Research in Autism Spectrum Disorders, $17,116-125$.

The Korean Society of Laryngology, Phoniatrics and Logopedics (2016). Laryngeal speech linguistic medicine: Understanding vocalization and speech therapy. Seoul, Korea: Panmun Education.

Türkmen, S., Cansu, A., Türedi, S., Eryigit, U., Sahin, A., Gündüz, A., \& Ahavit, I. (2012). Age-dependent structural and radiological changes in the larynx. Clinical Radiology, 67(11), e22-e26.

Wing. L. (1992). The handbook of autism. Routledge. London EC4P 4EE.

Yoon, H. Y. (2015). Different brain activation patterns of children with autism spectrum disorder during recognition of facial 
expression. Journal of Special Education \& Rehabilition Science,

54(1), 59-74.

\section{• 이정헌(Jung-Hun Lee)}

동신대학교 언어치료학과 석사

한국플로어타임연구소 소장

Tel: 02-6451-2929

Email: ftalking7572@gmail.com

관심분야: 신경발달장애, 자폐스펙트럼장애

\section{- 김고운(Go-Woon Kim)}

충남대학교 언어병리학협동과정 석사

한국플로어타임연구소 원장

Tel: 02-6451-2929

Email: kgony44@gmail.com

관심분야: 음성 인지, 자폐스펙트럼장애

- 김성태(Seong-Tae Kim) 교신저자

동신대학교 언어치료학과 교수

Tel: 061-330-3474

Email: voicekim@dsu.ac.kr

관심분야: 음성장애, 신경언어장애, 자폐스펙트럼장애 


\title{
자폐스펙트럼장애 아동의 후두 높이 및 음성 특성*
}

\author{
이 정 헌 ${ }^{1,2} \cdot$ 김 고 운 $^{2} \cdot$ 김 성 태 ${ }^{1}$
}

1동신대학교 언어치료학과, ${ }^{2}$ 한국플로어타임연구소

\section{국문초록}

본 연구의 목적은 자폐스펙트럼장애를 가진 아동의 후두 특성을 확인하고자 하였다. 자폐스펙트럼장애로 진단받 은 2 4세 아동 8 명과 같은 연령의 정상 대조군 42 명을 포함하여 총 50 명의 아동이 실험에 참여하였다. 모든 아동들 은 경추와 후두의 중앙시상면의 X-ray 영상을 촬영하여 두 군의 후두 위치를 비교하였다. 또한 모음 연장발화 시 음 성 샘플을 수집하여 음향 매개 변수들을 분석하였다. X-ray 검사 결과, 정상군의 설골 높이는 3세가 가장 낮았으며, 4 세에 후두 높이가 상승하였다. 다른 한편으로, 외이도에서 설골까지의 거리는 4 세가 가장 긴 것으로 나타났다. 이 와는 대조적으로, 모든 연령대의 자폐스펙트럼장애군의 설골 높이는 정상군보다 낮았으며, 연령에 따른 설골 위치 의 차이는 없었다. 음향학적 평가 결과, $\mathrm{PFR}, \mathrm{vFo}, \mathrm{vAm}$ 은 정상 대조군에 비해 자폐스펙트럼장애군이 통계적으로 유의미하게 높게 나타났다. 결론적으로, 자폐스펙트럼장애 아동들의 낮은 후두 높이는 언어발달의 지연과 관련이 있는 것으로 사료된다. 음향학적 변수들 중 음성 조절기능을 보여주는 PFR, $\mathrm{vFo}, \mathrm{vAm}$ 은 정상 아동과 자폐스펙트럼 장애 아동의 음질 차이를 보여주는 voice marker로 생각된다.

핵심어: 자폐스펙트럼장애, 후두 높이, $\mathrm{PFR}, \mathrm{vFo}, \mathrm{vAm}$

\section{참고문헌}

김영태(2014). 아동언어장애의 진단 및 치료 (2판). 서울: 학지사. 권정아(2014). 자폐증 개념의 역사를 통해 살펴본 DSM-5의 자폐 스펙트럼장애 진단에 대한 고찰: PDD-NOS를 중심으로, 순천 향인문과학논총, 34(1), 101-130.

김붕년, 김준원, 권미경, 윤선아, 강태웅, 한일웅(2017). 자폐 부모 교육 서울: 학지사.

윤효운(2015). 자폐스펙트럼 아동의 감성표현(얼굴)에 대한 뇌활 성화 반응 연구. 특수교육재활과학연구, 54(1), 59-74.

정옥란(2003). 언어병리해부학. 부산: 한국언어치료학회.

정금수, 성철재(2007). 자폐범주성 장애아동과 정상아동 의 문장

읽기에서의 운율특성 비교, 언어청각장애연구, 12(4), 625-642. 조경자, 김정기(2011). 자폐성향과 공감: 체계화능력 간의 관 계.

감성과학, 14(2), 245-256.

이정헌, 김고운, 김성태(2020). 자폐스펙트럼장애 아동의 음성 특 성. 재활복지공학회논문지, 14(3), 195-202.

\footnotetext{
* 본 연구는 이정헌(2018) 의 석사학위 논문을 수정 보안하여 작성한 것임.
} 